\title{
Kampen om den organisatoriske selvfortalling To skridt frem og to tilbage
}

Af Peter Beyer *)

\author{
A. Indledning \\ Formand for Ledelseskommissionen Allan Søgaard Larsen siger følgende1:
}

"Det er nu, det virkelige arbejde med at forbedre ledelsen i den offentlige sektor begynder, for anbefalingerne er ikke meget værd, så længe de kun står i vores rapport. Den virkelige udfordring bliver at få dem ud og leve. Jeg er derfor glad for den positive modtagelse, og jeg håber, at politikerne over en bred kam vil arbejde konstruktivt for, at vi med udgangspunkt i vores anbefalinger får skabt endnu bedre ledelse i den offentlige sektor til gavn for borgerne,"

"Forandringer skal komme både fra lederne selv, der skal sørge for 'at ledelseskasketten vender rigtigt', og så skal der over en bred kam skabes bedre rammer for lederne"

Denne artikel handler om et projekt, der på mange måder minder om den opgave, som Ledelseskommissionen lægger op til. Projektet havde til formål at styrke den organisatoriske selvfortælling i en større kommune x, at få genrejst arbejdsglæden i kommunen, at frigive energi, positive tanker og stolthed omkring arbejdspladsen, at etablere en fælles følelse blandt alle medarbejderne, at medvirke til en opblomstring af lavtlønsområdet, at vise at alle er vigtige og at skabe effektivitet via stolthed og entusiasme.

*) Peter Beyer er ingeniør og mangeårig ledelseskonsulent i større konsulentfirmaer. Han er phd i ledelsesudvikling fra CBS og har en lang erfaring som ekstern lektor på CBS. 
Artiklen beskriver et projekt, som var tæt på at komme i mål, men som alligevel ikke lykkedes. Beskrivelsen er forholdsvis detaljeret. Casen indeholder til sidst en række konkrete spørgsmål. Det er ikke meningen, at I som læsere skal svare systematisk på spørgsmålene, men vi håber, at de kan inspirere Jer til nogle generelle betragtninger og kommentarer. Vi håber at få nogle reaktioner fra Jer, som vi så vil samle i en efterfølgende artikel. Her vil vi anlægge et socialkonstruktivistisk perspektiv som udgangspunkt for en tænkt kulturforandring i kommunen. I kan sende Jeres tanker, vurderinger og løsningsforslag til Peter Beyer på mail pb.om@,cbs.dk. Frist for indsendelse er en den 29. oktober 2018. Vi håber at få svar fra Jer, der gør det muligt at skrive en mindre artikel i næste nummer, som så vil indeholde resultatet af dialogen om processen med kommentarer fra Peter Beyer.

\section{Oversigt over artiklen}

Artiklen indeholder 4 hovedafsnit:

1. Kort om projektet

2. Forberedelse af uddannelsesforløbet

3. Gennemførelse af uddannelsesforløbet

4. Evaluering af uddannelsen

Hvert af disse hovedafsnit indeholder to principielle elementer:

1. En detaljeret forløbsbeskrivelse

2. Nogle korte teoretiske indspark markeret således: $\mathrm{M}$ mmmmmm.

\section{Brugen af artiklens casebeskrivelsen, læsning og debatgrundlag}

I projektet ser vi kommunen som et system af værdier, meninger og grundlæggende antagelser, det medfører, at den ønskede forandring i sig selv også er en social konstruktion. Den ønskede ændring vi ske, hvis aktørernes fortolkninger og referencerammer forskydes.

Det vi vil høre Jeres mening om, er, i hvilken udstrækning casen fremviser generelle problemstillinger og paradokser, som I som læsere har erfaring med og holdninger til, samt hvilke barrierer og løftestænger der kan udnyttes til at opløse paradokserne.

Casen er forholdsvis detaljeret. Alt hvad der står i casebeskrivelsen, har såvel byrådet som direktionen og det øvrige øverste ledelseslag i kommunen set i forbindelse med projektforløbet. I 
får derved som læsere det samme beslutningsgrundlag, som beslutningstagerne i kommunen havde.

Det vi er interesseret i at få Jeres mening om er:

1. Hvad kan man med rimelighed forvente af en kommune som bestiller, og hvad kan uddannelsesinstitutionerne gøre for at give en kommunes beslutningstagere de nødvendige kompetencer?

2. Hvad kan man med rimelighed forvente af et konsulentfirma som udfører, og hvad kan uddannelsesinstitutionerne gøre for at give konsulenterne de nødvendige kompetencer?

3. Hvad kan der gøres for at sikre et robust og tillidsfuldt forløb, hvor bestiller og udfører i tæt samarbejde får løst de problemer, der dukker op?

En række konkrete spørgsmål, som vi vil bede Jer om at reflektere over, ligger sidst i casen bundet op omkring casens storyline. Vores primære formål er således at få en fornemmelse af, hvad vi som uddannelsesorganisation kan gøre bedre.

\section{Kort om projektet}

Projektet bestod i et "train the trainer" forløb, hvor vi som konsulenter skulle designe et 3 x 1 uges internatkursus for 31 instruktører, som kunne sætte dem i stand til at gennemføre et forløb for ca. 6.500 medarbejdere og ledere i kommunen.

Projektet skulle resultere i en kursusmappe med værktøjer og teknikker, som medarbejdere og ledere kunne benytte efter kursusforløbet samt en uddannelse af instruktørerne, som derefter skulle gennemføre det videre forløb i projektet.

Vi gjorde det på den måde, at materialet blev udformet under kurset af de 31 instruktører. Formålet med dette var, at instruktørerne, når de senere skulle undervise, havde sig selv med i deres materiale.

Det kritiske punkt i forløbet ville komme, når vores kursister mødte personalet i kommunen, et tidspunkt, hvor vi var færdige med vores del af opgaven, og hvor vi så ikke ville have mulighed for at gribe ind og korrigere. Fokus under de tre ugers forløb var derfor at opruste instruktørerne 
personligt og at skabe en teamfølelse, så instruktørerne kunne støtte hinanden under det efterfølgende forløb.

Projektets havde følgende aktivitetsforløb:

B. Forberedelse af uddannelsesforløbet

1. Opstartsmøde med direktionen.

2. Diagnose (en kommunal selfie).

3. Opstilling af projektets succeskriterier.

4. Formulering af en vision og et fælles værdigrundlag.

5. Afholdelse af mobiliseringsmøder.

C. Gennemførelse af uddannelsesforløbet

1. Gennemførelse af instruktøruddannelse.

2. Medarbejderkurser (Her var vi ikke med).

3. Gennemførelse af et byrådsseminar.

D. Evaluering af uddannelsen

1. Virkningsevaluering.

2. Efterspillet

3. Konklusionen

Opgaven var rimelig klart formuleret af kommunen, og vi som konsulenter var sikre på, at vi havde de kompetencer, der skulle til for at gennemføre opgaven, således som den var beskrevet.

\section{B. Forberedelse af uddannelsesforløbet}

\section{Opstartsmøde med direktionen}

På opstartsmødet med direktionen blev formålet med projektet formuleret således: byrådet, direktionen, ledere og medarbejdere skal:

1. Kende og opleve kommunens vision, værdigrundlag og målsætninger som klare pejlemærker.

2. Kunne demonstrere værdierne i forbindelse med eget arbejde.

3. Forstå og anerkende hinandens arbejds- og kompetenceområder på tværs af kommunen.

4. Føle stolthed over at arbejde i kommunen.

5. Forstå betydningen af, at alle fungerer som kommunens ansigt udadtil. 
6. Forstå nødvendigheden af udvikling og forandringer til glæde for samfundet.

7. Opleve frisættelse og selvstyring som middel til større arbejdsglæde og effektivitet.

8. Tage ejerskab for en ny måde at tænke og arbejde på.

Barren blev sat højt, projektet skulle give et markant løft af kulturen, og medarbejderne skulle lære at mestre selvledelse. Projektet skulle nå dette gennem et kursusforløb for samtlige ledere og medarbejdere i kommunen. Formålet med kurserne blev formuleret således:

- At den enkelte oplever fordele ved at arbejde gennem værdier frem for regler og styring.

- At give den enkelte frihed og mod til at tage mere ansvar.

- At medvirke til øget arbejdsglæde og fælles forståelse for, hvordan værdierne omsættes i praksis på tværs af faglige fællesskaber.

\section{Diagnosen, Den kommunale selfie}

Næste aktivitet var en diagnose, som havde til formål at identificere projektets udgangspunkt og risikoprofil. Dataindsamlingen til diagnosen bestod af 11 fokusinterview. Deltagerne fra kommunen var direktionen og 6 udvalgte ledere samt en fællestillidsmand. Under interviewrunden beskrev deltagerne det organisatoriske selvbillede således:

- Kommunen har en sikkerhedskultur, vi er bange for fodfejl. Et tidligere politisk slagsmål sidder dybt begravet i mange af os. Vi gør alle som vi plejer. Udvikling og nytænkning har det meget svært. Kommunen har en overvågningskultur. Vi vil gerne have en mere decentral styring, men kulturen i byrådet gør det vanskeligt for medarbejderne at agere.

- Fagforeningerne har en generel mistillid til kommunen. At gode initiativer omkring åbenhed og uddelegering af ansvar bliver bremset af fagforeningerne. Fagforeningerne har focus på de negative ting.

- Mange ledere er ikke gode rollemodeller. Mange ledelsesudmeldinger bliver utroværdige, fordi man ikke selv lever op til dem. Direktionen bør være bedre til at prioritere og delegere.

- Ledergruppen er delt i mange spørgsmål. Der mangler en forståelse for helheden fra mellemlederne. En implementeringsbeslutning er ikke det samme som en implementering.

- Holdningerne er så forskellige, at det giver uro. Der bliver kontrolleret for meget. Der er for mange regler og for få værdier i centralforvaltningen. Der er tendens til, at man lokalt møder borgeren som værdier og centralt som regler². Vi håber, at projektet kan være med 
til at mindske denne forskel. Det vil være rart, hvis projektet kan medvirke til en afbalancering af disciplin og frihed, dialog og diktater, etc.

- Vi er positiv over for de formulerede intentioner i projektet, men bekymrede over evnen til at implementere. Erfaringerne fra lignende projekter er manglende engagement fra lederne og skuffelse fra medarbejderne over, at det hele blot ebber ud.

- Det politiske klima er giftigt. Vi har en politisk liste (Byfornyerne), der tæsker systemet, hvis der bliver lavet fejl. Det smitter af på resten af organisationen. Vi har svært ved at leve op til de politiske udmeldinger. Vi ser os selv som en stor kommune med for mange politikere, der gør det svært at udføre arbejdet ordentligt. Det politiske klima er giftigt, vi er bange for at træffe beslutninger. Politikerne stiller urimelige spørgsmål, puster til ilden og sender egne holdninger og udokumenterede fortolkninger videre til pressen.

- Holdningerne til projektet er lunken. Vi tvivler på, at de "unge” instruktører kan lære de gamle og tunge bureaukrati-ledere noget og få dem til at lytte. Der skal mere til end værdiformuleringer.

- Endelig noget, der ikke bare er for toppen, men vi savner information om, hvordan der skal følges op, når kurserne er gennemført.

- Kommunen er også teknologisk bagud i forhold til andre kommuner. Vi har fx stadigvæk håndført papirjournal, ligesom vi fx heller ikke har indført elektronisk kalender.

Generelt var billedet, at medarbejderne ikke følte, at de blev udviklede. Man oplevede for mange forandringer og for få forbedringer. Ønsket til fremtiden var, at man ville blive stolte af hinandens arbejde hele vejen rundt.

På CBS fortæller vi at: ”Den organisatoriske selvfortælling er den fortælling, organisationen fortæller om sig selv og til sig selv. Den vil kunne vise, hvordan kommunen ser sig selv i forhold til andre kommuner og institutioner, i forhold til borgere og i forhold til den kontekst, kommunen befinder sig i. Den kommunale selvfortællingen er den fortolkningsramme, medarbejdere og ledelse har til rådighed for at forstå deres arbejdsplads, og de erfaringer man gør sig her. Når man arbejder med selvfortællinger, er det vigtigt:

- At anerkende aktørernes opfattelse af den organisatoriske virkelighed.

- At tilrettelægge et forløb, der kan blive meningsskabende på nye præmisser.

- At skabe rammer for forløbet, der vil hjælpe til at opnå aktørbevidsthed. 
- At arbejde med den kommunale selvfortælling som noget socialt konstrueret og derfor noget foranderligt.

- At sikre et forløb hvor man er åben omkring, hvad man gør, tænker og taler om og hvorfor.”

Resultatet af diagnosen blev afhandlet med den samlede direktion. Efter gennemgangen foretog vi en vurdering af projektets risikoprofil. Direktionen vurderede, at de eneste to risici, det ville være nødvendigt at overvåge tæt, var:

- Den generelle utilfredshed.

- Ejerskabet fra det politiske niveau.

\section{Opstilling af projektets succeskriterier}

Indikatorerne på succes blev formuleret således: At alle deltager i forpligtende dialoger. At alle føler målet. At værdien af projektet føles af alle på en gang. At al kommunikation går uden om forbehold, forventninger, magtkampe og positionshævdelse. At vi er fælles om interessen i det, vi taler om, når vi taler sammen.

Ser man indikatorerne i forhold til diagnosen, peger det på en total transformation af kultur og adfærd.

\section{Formulering af en vision og et fælles værdigrundlag}

Ideen i projektoplægget var at lade bearbejdningen af kommunens selvfortælling tage

udgangspunkt i kommunens værdigrundlag og vision. Værdigrundlaget blev formuleret således:

\begin{tabular}{|c|c|}
\hline Hvorfor er vi her? & $\begin{array}{l}\text { Hvordan vil vi have det med } \\
\text { hinanden? }\end{array}$ \\
\hline $\begin{array}{l}\text { Vi loser opgaver for borgerne } \mathrm{i} \\
\text { Kommune } \mathrm{x} \text { på grundlag af } \\
\text { falles værdier }\end{array}$ & $\begin{array}{ll}\cdot & \text { Ansvarlighed } \\
\cdot & \text { Udvikling } \\
\cdot & \text { Helhed } \\
\cdot & \text { Kvalitet } \\
\text { - } & \text { Brugerorientering }\end{array}$ \\
\hline Hvad er det rigtige at gøre: & Hvad står vi for: \\
\hline
\end{tabular}


- Dialog

- Effektivitet

- Rummelighed
Vi skaber udvikling og kvalitet $i$

åbent samspil med borgerne og

med hinanden.

Kommunens vardiformulering. Set i bakspejlet burde man have suppleret vardierne med konkrete adfardsformuleringer og derefter fäet magtsystemet til at tage ejerskab for formuleringerne.

Visionen blev udformet således:

- Kommunen er et center for vækst, og den skal derfor være attraktiv at bo og arbejde i.

- Kommunen er en servicevirksomhed, hvor åbenhed og kvalitet er bærende elementer.

- Kommunen skaber gode rammer for en mangfoldig udvikling i et levende samspil med omverdenen og gennem et udbygget samarbejde med andre kommuner.

- Kommunen er kendt som en dynamisk og værdiskabende arbejdsplads, der til stadighed udvikles i et samarbejde mellem borgere og medarbejdere.

- For alle i kommunen: byrådet, direktionen, lederne og medarbejderne gælder, at vi oplever kommunens vision og værdigrundlag som klare "pejlemærker". Vi forstår betydningen for egen rolle i forbindelse med eget arbejde. Vi forstår og anerkender hinandens arbejds- og kompetenceområder. Vi føler stolthed over at arbejde i kommunen. Vi anerkender betydningen af, at alle ansatte fungerer som kommunens "ansigt" udadtil, og vi forstår nødvendigheden af udvikling og forandringer til gavn for samfundet og dermed også for vores eget arbejde.

- Vi forstår, at ledelse med udgangspunkt i kommunens vision og værdier er en forudsætning for decentralisering og udlægning af arbejdsopgaver og for at kunne beherske en ny måde at tænke og arbejde på.

Senge om visioner: En vision er falles og delt når:

- Den bygger på og springer ud af medarbejdernes private visioner.

- Den løbende bliver videreudviklet.

- Den ikke er en løsning på et problem.

- Visioner, der er delte, vokser frem som sideeffekt af interaktionen mellem individuelle visioner.

- Visioner, der er agte delt, krever løbende dialog, hvor folk ikke blot foler sig frie nok til, at de tor udtrykke deres dromme, men også en dialog, hoor folk har lart, hvordan man lytter til de andres drømme. 
- Forskellen på mennesker, der er føjelige, og dem der er kommittede, er den, at de kommittede går ind for visionen med hud og hår.

I Senges bog The Fifth Disciplin er det beskrevet, hvordan man etablerer en falles og delt vision. I andringsteorien er visionen afgørende for at gennemfore en transformation. De gange jeg $i$ mit nasten 50 årige konsulentliv har oplevet en vision, der var falles og delt, kan talles på en hånd.

\section{Afholdelse af mobiliseringsmøder}

I projektforslaget havde vi lagt vægt på en indledende mobilisering af ledergruppen og fagforeningsrepræsentanterne. Når vi sammenholdt dette med vores oplevelser efterfølgende, var vores konklusion, at mobiliseringsaktiviteterne burde have været flere, og under ingen omstændigheder færre.

Mobiliseringsmøderne havde også til formål at give vigtige informationer, som kunne sætte instruktørerne i stand til bedre at ramme målgrupperne og diskutere med dem. Informationer som betød, at instruktørerne ikke skulle starte i et landskab uden kort.

Mobiliseringsmøderne viste, at projektforberedelsen havde været stærkt topstyret, uden at der var etableret nogen dialog ude i organisationen af betydning. Ledere og tillidsfolk så projektet som direktionens projekt. Der var intet reelt ejerskab. Man kunne godt se noget af det, projektet ville kunne give kommunen, men man følte, at projektet var noget, der kørte et andet sted. Man var ikke selv med.

Mobiliseringsmøderne blev kørt som store cafe-seminarer, hvor ideen var at lade dialogen få sit eget liv. Vores generelle erfaring var, at organisationer, når man samler medarbejderne på den måde, kan se problemerne og kender løsningerne.

En lille historie viser udgangspunktet. På det første møde var instruktørerne indbudt, for at de kunne tage temperaturen og se de ledere, de senere skulle undervise. En instruktør sad uden at give sig til kende ved et af bordene. Her førte en leder sig frem og sagde bl. a., at hvis en af hans medarbejderne tilmeldte sig et sådant kursus, så ville han blive fyret på stedet. Instruktøren fortrak derefter stille. Er ledelsesstilen magtbaseret, er værdiledelse en stor udfordring. 
Diagnosen pegede på, at der kunne forventes markant modstand fra visse dele af lederne grundet styringskulturen, den mangelfulde dialog og ressourceproblemer. Dette blev underbygget på mobiliseringsmøderne. Her blev der peget på følgende kritiske succesfaktorer: Kommunikation. Involvering. Dialog. Undgå at projektet opfattes som topstyret. Størst mulig åbenhed. At magtsystemet tager ejerskab, og at de nødvendige ressourcer afsættes.

\section{A. Mødet med tillidsrepresentanterne}

Som oplæg til cafeseminaret med tillidsrepræsentanterne gennemgik vi resultatet fra 43 spørgeskemaer, hvor vi havde stillet to spørgsmål:

1. Hvor ser I modstand, som vi alle bør tage hensyn til?

2. Hvor ser I støtte, som vi kan bruge til at sikre gode resultater for alle?

Her fik vi følgende svar på det første spørgsmål: Ledelsens holdning og uddannelse begrænser udvikling. Informationsniveauet har indtil nu været alt for lavt. Nu igen? Der er gennem årene taget mange tilløb, som aldrig er blevet til noget. Der er ikke tillid til, at det denne gang bliver til noget. Ikke alle har mod på den frisættelse, der ligger i projektet. Drejer det sig ikke igen i sidste ende om besparelser? Det giver bekymring for forløbet, at vi alle skal have den samme undervisning. Ret ressourcekrævende sammenlignet med de meget sparsomme ressourcer vi i dagligdagen kan få tilført. Medarbejderne burde have været inddraget tidligere. Er lederne klar til at lede med udgangspunkt i kommunens værdigrundlag?

Og på spørgsmål 2 fik vi følgende svar: Informationen og uddannelsen af tillidsrepræsentanterne kan være støtte til et godt resultat. Selvstyrende grupper. Opnormering er nødvendig. Tag medarbejdernes indvendinger alvorligt. Et kombineret møde mellem ledere og tillidsrepræsentanter med emnet værdibaseret ledelse.

De vigtigste punkter fra den efterfølgende cafediskussion var følgende: Direktørerne bør træde frem, så de kan høre, hvad der rører sig blandt medarbejderne. Tillidsrepræsentanterne skal være bindeled mellem medarbejdere og ledelse. De skal hjælpe alle medarbejderne med at komme frem med deres synspunkter. Tillidsrepræsentanterne bør have større indflydelse og tages med på råd af ledelsen. Vi ønsker at få større indflydelse på vores hverdag. Dialog på det enkelte arbejdssted om den lokale fortolkning af værdierne. At der bliver ryddet op i de uskrevne regler. Hul igennem. At lederne lader os tage et større ansvar. Forståelse for 
hinandens arbejdsområder. Mere ansvar i hverdagen. Værdierne kolliderer ofte med den kolde virkelighed. Kommunens syndrom - undgå fejl.

\section{B. Mødet med lederne}

Som oplæg til cafeseminaret med lederne gennemgik vi resultatet fra 44 spørgeskemaer, hvor vi havde stillet dette spørgsmål: Hvor ser I barrierer, som vi bør tage hensyn til?

De vigtigste svar var: At politikerne ikke tager ejerskab af projektet. At medarbejderne stiller krav til ledelsen, men ikke til sig selv. Stort arbejdspres, det er svært at finde det nødvendige slæk i dagligdagen. At projektet er topstyret. At ikke alle medarbejdere er parate til at tage ansvar. At vi som ledelse tør vise medarbejderne tillid. At sikre et kulturskifte fra kontrol til tillid.

På den efterfølgende cafediskussion blev der peget på følgende muligheder: Forankre et fælles grundlag. Etablere en fælles forståelse. Større åbenhed omkring fejl. Tilladt at diskutere holdninger. Dialog. At mødes på tværs af sektionerne i kommunen. Nytænkning og mulighed for at prøve noget nyt. Fra kontrol til tillid, større handlefrihed under ansvar.

Og på følgende barrierer: Projektet vil kunne stoppe andre tiltag. Vi er bange for at blotte os. At vi ikke kan ikke leve op til de nye roller. Frygt/utryghed ved: Ny lederrolle, medarbejderforventninger og økonomi. Topstyring. Forhistorien. Manglende information, dårlige erfaringer fra tidligere. Manglende tillid til hinanden. Kommunens ringe forandringspotentiale. Medarbejdere der efterspørger regler. I en kontrolkultur vil man dække sig ind ved at følge regler.

\section{Gennemførelse af uddannelsen}

\section{Instruktøruddannelsen}

På instruktøruddannelsen (3 gange af 5 dage internat) blev der arbejdet med følgende problemstillinger: Troværdige præsentationer. Introduktion af kommunens vision. Pædagogiske principper. Værktøjer til brug ved tilrettelæggelse af undervisningsforløb. Gruppedynamik. Konflikthåndtering. Præsentationsteknikker. Personlig stil, kropssprog, diktion mv. 
Kurserne for lederne og de øvrige medarbejdere blev udviklet på modul 2 og 3 i samarbejde med instruktørerne. De tre moduler foregik i et tæt og intensivt forløb med jævnt stigende krav til deltagerne.

\section{a. Modul 1: "DIG SOM FORMIDLER!"}

Formålet var at sikre deltagernes forståelse for og indlevelse i den afgørende rolle, den enkelte instruktør ville få i forbindelse med det videre forløb. At diskutere, præcisere og eksemplificere principperne i projektet sammenholdt med kommunens værdigrundlag og vision brugt i dagligdagen.

Endvidere var formålet at lære deltagerne at forberede og gennemføre et effektivt undervisningsforløb. At bibringe den enkelte pædagogisk indsigt, at kunne vælge virkemidler ud fra projektmål, situation og deltagerforudsætninger, samt at vurdere den enkelte deltagers stærke og svage sider i relation til det samlede mål for de tre kursusmoduler, samt at opsætte individuelle udviklingsplaner. At vurdere og afprøve den enkeltes personlige kommitment, samt at aftale en konkret personlig praktisk øvelse for hver deltager, som skulle gennemføres inden modul 2.

\section{b. Modul 2: "DIG SOM VARKTØJSMAGER"}

Formålet på modul 2 var at udbygge deltagernes kompetence gennem en dybere procesindsigt og en øget selverkendelse. At begynde udvikling af kurserne for ledere og medarbejdere og at vurdere den enkelte deltagers stærke og svage sider.

\section{c. Modul 3: "DIG SOM ANDRINGSAGENT"}

Formålet med modul 3 var, at tilføre deltagerne kompetencer, som kombinerer instruktør- og konsulentrollen med fokus på den enkeltes forudsætninger og implementeringseffektivitet. At fortsætte udvikling af kurserne for ledere og medarbejdere: Mål, struktur, lektionsplaner, AVmidler, etc. og at udvikle kursusdokumentation til kurserne for ledere og medarbejdere.

\section{Medarbejderuddannelsen (her var vi som konsulenter ikke med)}

Der blev derefter gennemført en lang række kurser. Hvert kursus blev evalueret ved afslutningen. Her er vurderingen fra kursus nr. 28. Sammentællingen er lavet på baggrund af en skala fra 1-5 hvor 5 er det bedste. 


\begin{tabular}{|c|c|}
\hline $\begin{array}{l}\text { Hvordan vurderer du dit } \\
\text { samlede udbytte af kurset? }\end{array}$ & $\begin{array}{l}\mathbf{4 , 4} \text { - Godt kursus/godt redskab til at } \\
\text { komme videre. Godt og lærerigt. } \\
\text { Inspirerende. Mange gode ideer. Gejst. }\end{array}$ \\
\hline $\begin{array}{l}\text { Har kurset levet op til dine } \\
\text { forventninger? }\end{array}$ & $\mathbf{4 , 7}$ - Ja mere end forventet. Positivt. \\
\hline $\begin{array}{l}\text { Hvordan har din egen } \\
\text { indsats været? }\end{array}$ & $\begin{array}{l}\mathbf{4 , 2} \text { - Været godt med. } \\
\text { Aktiv/lyttende/givet/bidraget. }\end{array}$ \\
\hline $\begin{array}{l}\text { Hvorledes vil du bedømme } \\
\text { kursets form og indhold? }\end{array}$ & $\begin{array}{l}\text { 4,4 - Alsidigt - en ny måde ar arbejde på. } \\
\text { God veksling mellem teori og praksis. } \\
\text { Spændende og afvekslende. Gerne mere } \\
\text { gruppearbejde. }\end{array}$ \\
\hline $\begin{array}{l}\text { Hvorledes vil du bedømme } \\
\text { begge instruktørers } \\
\text { pædagogiske og faglige } \\
\text { evner? }\end{array}$ & $\begin{array}{l}\mathbf{4 , 8} \text { - God - ikke kedelig. Meget } \\
\text { professionelt. Gode til at fastholde. } \\
\text { Smækkerlækkert. De er det "perfekte" par, } \\
\text { utroligt godt samarbejde. God humor - } \\
\text { forfriskende. }\end{array}$ \\
\hline $\begin{array}{l}\text { Har timetallet været } \\
\text { passende? }\end{array}$ & $\begin{array}{l}\mathbf{4 , 5} \text { - Ok - men når det er godt, kan der } \\
\text { godt bruges mere. Gerne en dag mere. }\end{array}$ \\
\hline $\begin{array}{l}\text { Hvordan har du følt dig } \\
\text { tilpas på holdet? }\end{array}$ & $\begin{array}{l}\text { 4,8 - God stemning. Godt med blandede } \\
\text { faggrupper. Vi har leet meget. }\end{array}$ \\
\hline $\begin{array}{l}\text { Hvordan synes du holdet har } \\
\text { fungeret? }\end{array}$ & $\begin{array}{l}\mathbf{4 , 7} \text { - Alle gik ind for samme sag. Fin } \\
\text { stemning. "Super". }\end{array}$ \\
\hline $\begin{array}{l}\text { Hvis kurset skulle afholdes } \\
\text { igen, hvad skulle vi så } \\
\text { eventuelt lave om? }\end{array}$ & $\begin{array}{l}\text { Ikke noget - det var bare så godt. Godt } \\
\text { med et opfølgningskursus. Færre } \\
\text { deltagere på et hold - hesteskoopstilling. }\end{array}$ \\
\hline
\end{tabular}

Kursusevalueringerne var langt overvejende positive. At de viste et mere positivt billede end den senere virkningsevaluering, skyldes formentlig, at de blev foretaget tidligt i forlobet på kurser med blandede deltagere, og hvor diskussionerne på kurserne endnu ikke havde ramt de institutioner og afdelinger, deltagerne kom fra. 


\section{Eksempler på værktøjer}

For at illustrere kurserne følger her nogle af de værktøjer, som kursusdeltagerne arbejdede med.

\begin{tabular}{|c|c|}
\hline Øvelse & Oplæg \\
\hline $\begin{array}{l}\text { At se betydningen de kommunale } \\
\text { selvfortællinger. } \\
\text { At blive bevidst om, hvad vi går } \\
\text { og fortæller om kommunen. } \\
\text { At diskutere, hvordan vi kan få de } \\
\text { gode historier frem? }\end{array}$ & $\begin{array}{l}\text { Fortæl en god og en dårlig historie. } \\
\text { Diskutér hvilken af de to historier, som } \\
\text { med størst sandsynlighed bliver } \\
\text { fortalt/hørt. } \\
\text { Hvis den dårlige historie vælges, skal I } \\
\text { tænke på: } \\
\text { Hvordan den kan fortælles positivt. } \\
\text { Hvordan vi finder de gode historier. }\end{array}$ \\
\hline $\begin{array}{l}\text { At diskutere konkrete } \\
\text { selvfortællinger. }\end{array}$ & $\begin{array}{l}\text { Hver gruppe skal blive enige om en god } \\
\text { og en dårlig historie om kommunen. } \\
\text { Historierne skal kobles op på }\end{array}$ \\
\hline Inddeling i grupper. & kerneværdierne. \\
\hline Lederøvelse. & $\begin{array}{l}\text { Hvilke muligheder giver projektet dig for } \\
\text { bedre at kunne udfylde din lederrolle og } \\
\text { udvikle din arbejdsplads? }\end{array}$ \\
\hline $\begin{array}{l}\text { Gruppeøvelse værdien } \\
\text { ansvarlighed }\end{array}$ & $\begin{array}{l}\text { Hver gruppe skal beskrive "ansvarlighed" } \\
\text { via } 2 \text { spørgsmål: } \\
\text { 1. Hvilke forudsætninger skal der til? } \\
\text { 2. Hvilke virkninger vil større } \\
\text { ansvarlighed have i hverdagen? } \\
\text { Hver gruppe redegør for deres resultater }\end{array}$ \\
\hline Walk and talk. & $\begin{array}{l}\text { De første } 10 \text { minutter fortæller den ene, } \\
\text { mens den anden lytter (uden at afbryde). }\end{array}$ \\
\hline $\begin{array}{l}\text { Tal om hvilke muligheder de } 5 \\
\text { værdier giver i arbejdet. } \\
\text { Kursisterne går to og to en tur i } \\
\text { det fri, hvor de forsøger at } \\
\text { besvare spørgsmålet: Hvilke } \\
\text { muligheder giver projektet dig } \\
\text { for bedre at kunne udfylde din } \\
\text { rolle og udvikle din arbejdsplads? }\end{array}$ & $\begin{array}{l}\text { De næste } 10 \text { minutter er rollerne byttet } \\
\text { om. } \\
\text { De følgende } 10 \text { minutter bruger parret til } \\
\text { at udvælge } 2 \text { svar på spørgsmålet. } \\
\text { Disse svar skrives på en flipover, når man } \\
\text { kommer tilbage til lokalet. } \\
\text { I plenum diskuteres kursisternes forslag } \\
\text { til egne roller og udvikling af } \\
\text { arbejdspladsen. } \\
\text { Derefter sammensættes forslagene med de } \\
5 \text { værdier. }\end{array}$ \\
\hline
\end{tabular}




\section{Gennemførelse af et byrådsseminar}

Under forløbet blev vi bedt om at gennemføre et seminar for byrådet. Alle politikere i byrådet deltog på nær politikerne fra Byfornyerne.

På seminaret blev byrådet bedt om at svare på en række spørgsmål ved at skrive svarene på postit sedler og sætte svarene op på et ”Brown Paper” under de aktuelle spørgsmål. Der fremkom følgende billede:

\section{Er I enige om mål og visioner?}

Vi mangler evnen til forpligtende at formulere overordnede mål for kommunen. Der mangler fælles mål. Der ønskes en mere fremadrettet politik.

\section{Fungerer kommunikationsprocesserne fornuftigt?}

Vi drukner i for detaljeret information, vi mister overblikket. Forskydningen af beslutninger fra det politiske niveau og ud i yderste led virker indimellem uklar. Behov for klare udmeldinger om personalepolitikken. Der mangler overordnede rammer for tilbagemeldinger. Mere dialog om nye politiske tiltag, før sagerne går i udvalg og byråd. Det er et stort problem, at der lækkes til pressen fra lukkede møder, samt at der i stor stil videregives fortrolige dokumenter. Lokalavisens håndtering af stoffet er problematisk. Der er for mange rapporter med fyld. Der er forskellig opfattelse af, hvad der er væsentligt. Vi bliver bevidst druknet i detaljer. Pressens håndtering, der er ikke salg i de positive ting, derfor er det kun de dårlige ting, der bliver offentliggjort. Der er ikke "hul” igennem, således at vi ved, hvad der reelt foregår nede på borgerniveauet. Det gør os sårbare. Der bør være respekt omkring fortrolige lukkede sager.

\section{Har I en effektiv mødekultur?}

Mødekulturen er dårlig. Det er et problem, når byrådsmedlemmer ikke accepterer beslutninger, når de er taget, også når man er uenig i beslutningen. Man bør ikke kommentere beslutningerne på de næste 7 byrådsmøder. Der er tendens til, at byrådsmøderne udvikler sig til, at alle står og siger, hvad de tror, andre mener eller har ment, i stedet for at lytte og se fremad. De politiske beslutninger kører ind imellem zig/zag kurs gennem den demokratiske proces. Byfornyernes mange ændringsforslag i byrådssalen. Små sager drukner tit de store sager. Byrådsmedlemmerne skifter standpunkt fra udvalg og til byrådssalen. Manglende dialog om, hvad byrådet er enige om. Spørgsmål i spørgetiden eksploderer. Vi mangler tiden til at få overblik. For mange skifter 
mening for tit. Møderne er for lange. Vi behandler alt for mange enkeltsager. Vi trækkes rundt i manegen angående reglerne for spørgetid. Det er, som om de enkelte medlemmer i grupperne ikke i tilstrækkelig grad er enige indbyrdes.

\section{Er den indbyrdes anstandighed og respekt på plads?}

En sag har altid to sider. Når borgere klager til os politikere, er det vigtigt at høre modparten, inden man går videre med sagen. Der er mangel på anstændighed og mangel på respekt for hinanden og hinandens meninger. Det er et problem, når byrådsmedlemmer går til pressen med sager fra "lukket dagsorden”. Vi kan ikke stole på hinanden.

\section{Kan byrådet udfylde sin rolle som effektivt beslutningsorgan?}

Byfornyerne vælger at stå udenfor. Det er et problem, at vi er totalt uforudsigelige som byråd.

Det giver utryghed i organisationen. Der mangler loyalitet over for fællesbeslutninger, som man selv har taget del i. Vi ønsker tillid og information. Vi er usikre på, hvor de enkelte grupper står. Der er brug for, at ledere påtager sig lederroller på alle niveauer. Megen sagsbehandling. Tunge sager ligger sidst på møderne, hvor man ikke tænker optimalt. Der er for meget fokusering på problembørn.

\section{Er samspillet mellem byråd og direktion tilfredsstillende?}

Det er et problem, når byrådsmedlemmer angriber embedsmændene i åbne byrådsmøder. Vi skal vedstå vores politiske ansvar i relation til direktionen. Vi mangler synlig ledelse fra direktionen. Vi har behov for større kompetence på det boligpolitiske område. Vi påtager os et ansvar, vi hverken kan eller bør forsøge at leve op til med de mange detaljerede rapporter. Vi bør tilrettelægge tingene sådan, at vi kan arbejde ud fra fuld tiltro til embedsmændene.

\section{Er den økonomiske styring på plads?}

Vi laver tillægsbevillinger uden dækning. Økonomisk uansvarlighed. Økonomi når lommen er tom. Vi mangler overordnet økonomisk ansvarlighed. Vi kalder salget af arvesølvet for besparelser. 


\section{Er der balance mellem samarbejde og individuel profilering?}

Vi lader Byfornyerne overtage dagsordenen. "Visse" har et stort behov for at markere sig. Individuel frem for kollektiv profilering. Der bruges mange ressourcer på småtingsafdelingen på grund af personlig profilering. Møderne trækker i langdrag.

Problembilledet blev resumeret i følgende hovedpunkter:

- Mål og visioner er ikke delte.

- Kommunikationsprocesserne skaber problemer.

- Mødekulturen er ineffektiv.

- Anstændighed og gensidig respekt mangler.

- Byrådet som magtsystem er ineffektivt.

- Tilliden mellem byråd og direktion skal styrkes.

- Økonomi håndteres med hovsaløsninger, der udløser efterfølgende slagsmål.

- Problemerne giver mulighed for nulsumsspil og individuel profilering.

For at skabe en bedre arbejdssituation blev byrådet derefter enige om følgende initiativer og spilleregler:

\begin{tabular}{ll}
\hline Mål/visioner & $\begin{array}{l}\text { Der skal formuleres en fælles politik for byrådet, vision, spilleregler, } \\
\text { hovedmål, etc. }\end{array}$ \\
\hline Kommunikation & $\begin{array}{l}\text { Der aftales bedre spilleregler med lokalavisen, fx at man ikke bør hænge } \\
\text { enkeltpersoner ud i avisen med navns nævnelse, når disse personer ikke har } \\
\text { en chance for at forsvare sig. Der opstilles regler for stopning af lækage af } \\
\text { fortrolige oplysninger. Det er i øvrigt klart ulovligt. }\end{array}$ \\
\hline Mødekultur & $\begin{array}{l}\text { Der indføres hårdere tidsstyring af talerlisten. } \text { Endringsforslag, der dukker } \\
\text { op under byrådsmøderne, afvises. Tunge sager sættes først på dagsordenen. }\end{array}$ \\
& $\begin{array}{l}\text { Beslutningerne i udvalgene står vi ved. Der må ikke rykkes rundt på } \\
\text { dagsordenspunkterne. Der sættes deadline på ændringsforslag. }\end{array}$ \\
\hline $\begin{array}{l}\text { Anstændighed/ } \\
\text { respekt }\end{array}$ & $\begin{array}{l}\text { Beslutningerne er taget, når beslutningerne er taget. } \\
\text { Byrådets rolle }\end{array}$ \\
$\begin{array}{l}\text { Der udformes en politisk platform for de enkelte politiske grupperinger, et } \\
\text { manifest eller lignende, så grupperne kan se, hvor de har hinanden. }\end{array}$
\end{tabular}




\begin{tabular}{ll}
\hline $\begin{array}{l}\text { Byråd kontra } \\
\text { direktion }\end{array}$ & Det er byrådets opgave at sikre, at der er politisk flertal. Det er direktionens \\
& opgave at sikre, at forslagene er lovlige. De budgetlagte forslag behandles, så \\
& der er kortere tid fra beslutning til handling. Byrådet laver strategien, \\
& direktionen laver handlingsplanerne. Forvaltningsdirektørerne bør måske i \\
& højere grad komme med på økonomiudvalgsmøderne. Evt. nye \\
& rollebeskrivelser for direktionen bør ses i relation til kontraktstyringen. \\
& Direktionen bør være mere synlig eksternt, fylde stillingsbeskrivelsen ud. \\
& Der afholdes uformelle summemøder med direktionen efter byrådsmøderne. \\
& $\begin{array}{l}\text { Byrådet bør arbejde med forventningsafstemning med borgerne omkring den } \\
\text { kommunale service fx i forbindelse med strategi-notaterne. Man bør } \\
\text { markedsføre målsætningen om balance i økonomien. Der bør principielt ikke } \\
\text { gives tillægsbevillinger. Proceduren med årlig budgetlægning med } \\
\text { inddragelse af institutionerne bør være en fast foreteelse. }\end{array}$ \\
\hline
\end{tabular}

\section{Foreløbig liste over initiativer og spilleregler}

Byrådet formulerede følgende fælles vision:

- Vi vil arbejde ud fra hensyn til borgere og medarbejdere frem for politisk profilering.

- Vi arbejder med vision og strategi frem for detalje.

- Vi medvirker i videst mulig omfang til at skabe tryghed for medarbejderne i kommunen.

- Vi arbejder som byråd i tillid til medarbejdernes kvalitet.

- Vi arbejder for en positiv udvikling for kommunen.

- Vi arbejder for en kultur præget af åbenhed og ærlighed og tillid.

- Vi arbejder ud fra fælles værdier og fælles mål.

- Vi fungerer som ledere og ikke som kontrollører.

- Vi viser loyalitet over for beslutninger.

- Vi lever med fejl i den udstrækning, de giver anledning til laring.

- Vi arbejder ud fra et positivt menneskesyn.

- Vi giver klare udmeldinger nedad.

- Vi arbejder for at tydeliggøre det, byrådet er enige om, og dermed hvad fundamentet er for udviklingen i kommunen de nærmeste år.

- Vi arbejder på baggrund af en effektiv dialog. 


\section{De forste trin $i$ det videre arbejde}

Som byrådsseminaret sluttede, så det nu ud til, at der nu var fodslag og ejerskab i magtsystemet, så de følte problemer i kommunen kunne fjernes, og så der kunne skabes en ny kommunal selvfortælling.

Byrådet blev enig om følgende første skridt:

1. Borgmesteren indkalder gruppeformændene for de grupper, der var repræsenterede på mødet. Resultaterne fra mødet drøftes igennem, og en færdig handlingsplan, mål, spilleregler mv. udarbejdes.

2. Der udarbejdes en fælles pressemeddelelse.

3. Direktionsmødet holdes snarest på baggrund af drøftelserne her. Dette møde må ikke bremses af arbejdet med spillereglerne. Tema for mødet: Hvordan kan byrådet medvirke til, at direktionen fungerer så godt som muligt.

En årsag til at man ikke kan, vil kunne findes i den organisatoriske selvfortælling, hvis denne viser en markant mangel på tiltro. Rosabeth Moss Kanter, der er professor ved Harvard University, har i sin bog 'Confidence' (2006) skitseret, hvordan tiltro eller mangel på tiltro kan afgøre, om en gruppe bliver et vinderhold eller et taberhold. Bogen er baseret på surveys af mere end 1200 organisationer. Hendes konklusion er, at svaret ligger i os selv.

Enhver organisation oplever opture og nedture, men tiltro er nøglen til at fastholde evnen til at vinde. Om en gruppe vil vinde eller tabe, kan måles på den grad af tiltro, som gruppen medlemmer har. Tiltro er broen mellem forventninger og præstationer. En gruppe, der oplever vedvarende succes, har ofte øget tiltro. Personer, som er tilbøjelige til at tro på sig selv, arbejder hårdere, længere og gør en større indsats for at sikre, at de bevarer troen på sig selv. På den anden side vil en gruppe, der oplever fiaskoer, få et fald i tiltro, da dens medlemmer vil finde det sværere at samarbejde, og at blive mere kvalificerede og dermed vil de ende i en ond spiral.

Tiltro skal sikres på følgende fire niveauer:

1. Tiltro til sig selv: et følelsesmæssigt klima med høje forventninger.

2. Tiltro til hinanden: positiv, støttende, holdorienteret adfærd.

3. Tiltro til systemet: Organisatoriske strukturer og rutiner, der styrker ansvarlighed, samarbejde og innovation.

4. Tiltro til omgivelserne og til adgang til de nødvendige ressourcer. 
Det at tabe sker ikke pludselig. Det udvikler sig over tid. Det er resultatet af kombinationen af faktorer, hvor medlemmerne i gruppen reagerer på dysfunktionelle måder. Man kan ikke lide at være tabere. Det resulterer i manglende kommunikation, hemmeligheder og isolation, som forstærker problemet. Man snakker mindre sammen og finder syndebukke. Endvidere har man tendens til at skyde skylden på de andre, og de andre har tendens til at forsvare sig uden at overveje de organisatoriske følgevirkninger. En sådan gruppe vil opleve følgende:

- Kommunikationen falder, man undgår ubehagelige samtaler om problemer.

- Kritik og bebrejdelser øges, man gør alt for at undgå selvkontrol.

- Respekt falder, man føler sig omgivet af middelmådighed.

- Isolering øges, man ønsker ikke at blive mindet om andres svigt.

- Fokus vendes indad, man handler egennyttigt.

- Kløfterne udvides og uligheder vokser.

- Initiativet falder. Man er lammet af angst.

- Negativitet spredes og reducerer alles humør.

For at skabe en kultur baseret på tiltro, skal man forstå, at ansvarlighed, samarbejde og initiativ er afgørende for tiltro. Når dialogen reduceres, er ansvaret tabt. Derfor er opgaven at etablere ansvarlighed ved at formidle information på en måde, som deltagerne forstår, fremhæve problemer, kommunikere forventninger og vise mod til at indrømme medansvar. Dernæst skal teamwork fremmes, så alle føler sig som en del af holdet. Endelig skal man være åben for nye ideer og måder at gøre ting på, man skal se hinanden som kompetente og markere små sejre.

\section{Evaluering af uddannelsesforløbet}

\section{Virkningsevaluering}

I budgetteringen af projektet var der indlagt en slutevaluering, efter at kurserne var afholdt.

Medens kursusevalueringerne blev foretaget for et hold ad gangen, hvor deltagerne var blandede, så blev virkningsevalueringen foretaget for alle medarbejderne på en gang. Det betød, at vi nu kunne få en evaluering for de forskellige områder i kommunen. 
Det var besluttet, at medarbejdere skulle blandes, således at der på hvert kursus deltog medarbejdere fra forskelligartede arbejdspladser. Baggrunden var, at medarbejderne skulle lære hinanden at kende på tværs af de forskellige faggrupper og derigennem få en fælles oplevelse af den kommunale virkelighed.

Når man sammenholdt med de kursustilbagemeldinger, der løbende blev opsamlet, så fremgik det, at kursusdeltagerne satte stor pris på, at man mødte andre fra helt forskellige faggrupper. Man fik lært nye sider af kommunen og fik syn for, at også de andres arbejde var vigtigt. Beslutningen havde dog den ulempe, at man ikke kunne starte det konkrete lokale værdiarbejde, før end alle fra et givent område havde været på kursus. Derfor lå slutevalueringen ca. $1 / 2$ år efter, at de sidste kurser var afholdt. Slutevalueringen viste følgende billede.

Generelt var værdier ikke blevet mere synlige i det daglige, end de altid havde været, ligesom medarbejderne heller ikke følte sig inddraget i værdiarbejdet. Der var dog en spredning på svarene. Det stemte med kommentarerne, der viste, at mange ikke oplevede det nye i projektet. Kommunens værdier var i spil på det snævre personlige plan, men de var ikke kommet i spil på det organisatoriske plan. En ændret kommunal selvfortælling, kvalitetsløft i den leverede service, frisættelsen af medarbejdere, synergi og forbedret arbejdsmiljø forudsatte, at værdierne var i spil på det organisatoriske plan.

Medarbejderne forstod formålet med projektet og syntes, det var vigtigt, at det lykkedes. Kommunikationen omkring projektet, politikernes og ledelsens evne til at gå i front, motivation og fornyelse vurderedes som utilstrækkelig. Konklusionen var, at der manglede ledelsesdrivkraft. På nær nogle steder så det ikke ud til, at ledelserne gik forrest. Man var måske fanget i en ventenpå-hinanden-situation.

De fleste ledere angav, at de lagde vægt på fornyelse og forandring, og at de tog informationsopgaven alvorligt. Mange ledere følte sig ikke fuldt rustede til opgaven med den lokale implementering. De vurderede dog deres medarbejdere relativt højt.

Ledernes vurdering var, at projektet og dermed større medledelse fra medarbejdernes side, ville have en positiv effekt på deres arbejdssituation som leder. Denne vurdering var interessant, idet værdiledelse stiller endog meget store krav til lederne, og idet det fremgik af 
medarbejderudsagnene, at visse ledere formentlig burde skifte personlig lederstil for at kunne lede gennem værdier. Man skulle flytte stilen fra at være magtbaseret og kontrollerende til at være baseret på accept og inddragelse. Det er en meget svær omstilling, især hvis man i lang tid har haft en magtbaseret lederstil. Af medarbejderkommentarerne så det heller ikke ud til at være lykkedes i større omfang.

Man gav ikke en høj karakter for magtsystemets ejerskab og synlige ledelse. Det passede meget godt med, at man ikke følte sig helt klædt på til opgaven.

Ledelsen blev bedømt ensartet højt i en social institution (gns.=4,6), og ensartet lavt i en skole (gns.=2,0). Det stemte overens med den fornemmelse, man fik af bemærkningerne, at man i skoleområdet i højere grad ønskede at bruge kræfterne anderledes end på projektet. En udgangsholdning, der formentlig har betydet, at man har lært mindre, end man har haft brug for at lære og kunne have lært.

Nogle af de institutioner/afdelinger, der ikke var begyndt at implementere værdierne, var også dem, hvor ledelsen og medarbejderne havde det dårligst med hinanden. En ledelse, der har et dårligt forhold til medarbejderne, vil have langt sværere ved at komme i gang end ledelser, der i udgangspunktet har det godt med deres medarbejdere. Det var endvidere tankevækkende, at nogle af disse ledere samtidig angav, at de i høj grad styrede efter værdier frem for regler. I det følgende har vi taget nogle få udsagn og derefter kommenteret dem. De faldt i fire grupper.

a. Det har vi altid gjort

- Jeg arbejdede allerede inden kurset efter principperne. Jeg har bare aldrig rigtig tankt over det. Det falder mig bare helt naturligt.

- Da jeg altid har arbejdet på den måde, har projektet ikke haft indflydelse på mig.

- Jeg foler ikke, at vores arbejdsområde er andret markbart $i$ "vores hus"; men jeg håber, at projektet har kunnet hjalpe kursister på andre arbejdspladser.

Vi tolker resultaterne derhen, at det ikke var lykkedes at give medarbejderne oplevelsen af, hvordan kontrol og frisættelse balanceres. Dette er med til at fastholde medarbejderne og lederne i det gamle mønster. 
Beyer / Kampen om den organisatoriske selvfortælling

Opgaven med at skabe balance mellem kontrol og frihed blev ikke lettere med de løbende avisskriverier omkring projektet, og hvor de fleste indlæg gik på overskridelser, og at pengene kunne bruges bedre hvis kontrollen havde været skarpere, mens ingen af indlæggene fortalte, hvad projektet rent faktisk sigtede på. Denne gruppe udgøres formentlig af ansatte, der mener, at når man blot lever op til sit fags faglige standard, så er man nået i mål.

b. Vi skulle have gjort noget andet

- Kurserne kunne godt vare kortet af til en dag. Når kommunen mangler penge, mener jeg, at pengene kunne vare brugt anderledes. Skolevasenet er "udsultet", vi mangler "redskaber", har gamle bygninger, og er 20 år bagud.

- Tre påtvungne spilddage med dyre ord. Samtidig tre ugers forstyrrelse af vores undervisning. Folkeskolen har mere brug for, at der bliver givet ressourcer til undervisningsmidler, lokaleforbedringer, relevante kurser til larerne og fred til at undervise.

Denne holdning viser medarbejdere, der formentlig har været modstandere fra starten af, og som nu også bekræftes i, at de har haft ret hele tiden, fordi der ikke har været synligt ejerskab fra magtsystemet. En markant modstand fra skolevæsnet er også tankevækkende, fordi skolevæsnet altid har kæmpet for pædagogisk frihed, et tilbud, der netop lå i projektet. Denne gruppe udgøres formentlig af ansatte, der har fokus på egne lokale miljøer og egne kortsigtede gevinster, der kunne høstes.

c. Mine ledere dur ikke - og der er for meget kontrol

- Der er ingen opfølgning på projektet, vores leder kører sit eget løb! Ledelsen lytter ikke til hvad personalet ønsker!

- Ingen inddrager mig $i$ arbejdet med vardierne,jeg tager selv initiativ til mange ting/ideer, men vores leder ved altid bedre, men ofte er det ikke hendes tankegang, der er den bedste.

- Projektet barer prag af, at det er en panik løsning, som direktionen er kommet med. Der er INGEN i ledelsen, som har fattet, hvad projektet går ud på.

- Der er fortsat tendens til fejlfokusering og kontrol.

Vi tolker bemærkningerne derhen, at hvis der på en arbejdsplads ikke er sponsorer, som er højt motiverede for at gennemføre projektet, og som fungerer som ildsjæle, så brækker 
implementeringen over. Formentlig fordi styringen, adfærden og udmeldingerne fra politikere og direktion opleves uændret med fokus på politiske skænderier, kontrol og regelstyring. Vores spørgsmål her er: Kan byråd og den øverste administrative ledelse se sig selv i øjnene og med god samvittighed sige, at man hele vejen rundt agerer værdibaseret, eller har man ladet den videre værdibasering og forankring været organisationens problem alene? Denne gruppe udgøres af medarbejdere, der måske har forstået projektet, men som føler, at kulturen i magtsystemet gør implementeringen umulig.

\section{d. Det har givet et klart løft}

- Vi tager storre selvstandige beslutninger uden risiko. Jeg foler mig verdsat $i$ mit arbejde og som kollega. Vi bliver hørt og spurgt. Ansvaret for arbejdet er uddelegeret til den enkelte.

- Verdigrundlaget er ofte til debat i medarbejdergruppen. Der er storre åbenhed, dialog, personlig udvikling og et falles ansvar for den daglige trivsel og kvalitet.

- Jeg er glad for, at vi "almindelige" medarbejdere også fär lov at føle, at vi er noget vard og $i$ stand til selv at traffe beslutninger.

Kommentarerne i denne gruppe underbygger den oplevelse, man får, når man læser kursusevalueringerne, nemlig at kurserne har sat medarbejdere og ledere i stand til at arbejde med værdier på det personlige plan og et stykke af vejen også på institutionsplan. Flere steder var der en spirende kulturudvikling. Denne gruppe medarbejdere havde formentlig oplevet, at projektet har givet et løft og en ny lokal selvfortælling.

Et særligt kendetegn for kommuner er, at de er værdibrede. En kommune består af flere faglige miljøer med hver deres faglighed. Det giver følgende udfordringer ifølge professor Torben Beck Jørgensen:

1. Kommuner har et mindre forandringsvolumen.

2. Deres interessenter er mindre tilfredse.

3. De er underlagt mere kontrol.

4. De bruger flere kræfter på at koordinere.

5. De har et tungere ledelseslag.

6. De er mindre gennemsigtige.

7. De bruger mere traditionelle besparelsesmetoder, grønthøster, etc.

8. De har en tungere gang på jorden end mange andre organisationer. 
Dertil kommer, at de er underlagt en politisk styring, hvor magtsystemet består af et konglomerat af beslutningstagere, hvis opgave det er at kombinere deres politiske programmer med dag til dag politikken. Udfordringen er at undgå, at styringen udvikler sig til enkeltsagsstyring, politisering og udprægede nulsumsspil.

\section{Efterspil}

Men så kom budgetoverskridelser frem i lyset. Alle svømmer baglæns. Vi er nu tilbage i den gamle onde sløjfe. Politikerne udstiller hinanden i de offentlige medier. Følgende debat kunne læses i lokalavisen.

Dag 1: Administrationsdirektøren vasker hænder, den frie liste ser en mulighed for profilering: Administrationsdirektøren lægger i en netop udsendt redegørelse afstand til den aktuelle sag om løbsk økonomi i projektet, citat: Kommunaldirektoren har fra begyndelsen selv varetaget den daglige, ledelsesmassig styring, herunder økonomi. Jeg kender derfor ikke forholdene i detaljer og tager forbehold for mulige unøjagtigheder.

Det er tydeligt, at det ikke er en samlet direktion, som står bag projektet. I sin redegørelse lagger administrationsdirektoren klart afstand til projektet, og tager ikke medansvar, siger gruppeformanden for den frie liste.

\section{Samme dag: Byfornyerne godter sig:}

Naste skridt hedder afsked, smid ham ud. Sådan lyser dommen over kommunaldirektøren fra gruppeformanden for Byfornyerne. Nu er den gal med projektet. Der er for mange sager af den slags, og jeg er bange for, at der kommer flere. Det er os byrådsmedlemmer, der skal stå frem og tage skraldet hver gang. Det er jeg ked af. Borgerne må tro, vi er sindssyge oveni hovedet.

Hvis byrådet blot uddeler endnu en påtale, så skal kommunen snart have en mand ansat til at holde styr på direktionens samling af neser.

Samme dag: Der kastes mere snavs på banen, Der går ikke røg af en brand --:

Avisen har modtaget underretning om, at der vist var noget tilsvarende, da han var kommunaldirektør i den tidligere kommune. Denne kommune ville også sende de ansatte på kursus, og det kom til at koste kommunen en uventet regning på op imod en mio. kr. 


\section{Hertil svarede den tidligere kommune:}

Det var ikke kommunaldirektorens skyld, siger den tidligere kommunes borgmester. Medarbejderne skulle på kursus, men der gik politik $i$ den måde, nogle mennesker folte sig forbigået på. Når man laver noget nyt som dette, skal man dakke alle hjorner af. Vi havde nok glemt at tage fagforeningerne og isar Danmarks Larerforening $i$ ed, forklarer borgmesteren. Det forte til at nogle blev sure og gik bag kommunaldirektorens ryg til arbejdsministeren. Lobbyarbejdet bar frugt, og reglerne blev andret under forløbet. Projektet, der ifølge de gamle beregninger var udgiftsneutralt, kom derfor til at koste mellem en halv til en mio. kr. ekstra. Men kurserne var en succes. Vi bruger dem stadig, men nu betaler vi det hele selv.

\section{Dag 5 Byrådsflertal klar med kniven:}

Direktørens netop udsendte redegørelse om løbsk økonomi i et kommunalt kursusprojekt, som uventet har kostet kommunen 7.2 mio. kr., har ikke tilfredsstillet byrådet. Kun byrådets medlemmer af Byfornyerne samt et af de øvrige medlemmer taler åbent om, at de vil have kommunens øverste administrative chef afskediget.

Det er totalt gak det her. Min tillid til kommunaldirektoren er borte. Jeg har ikke skyggen af tillid til, at den mand har evner til at styre kommunens økonomi endsige til at oplyse byrådet ordentligt, inden vi traffer beslutninger, siger gruppeformanden for Byfornyerne. Derfor må han bort.

Jeg har ikke behov for at spille handlekraftig, inden jeg selv har talt med kommunaldirektøren. Kommunen og dermed byrådets medlemmer skal behandle sit personale herunder kommunaldirektoren anstandigt, siger gruppeformanden for den frie liste.

\section{Dag 5: Topchef på porten uden løn:}

Hvis et byrådsflertal beslutter at afskedige kommunaldirektøren, så hænger kommunen som udgangspunkt på en lønudgift i tre år endnu. En udgift, som gruppeformanden for den frie liste, dog ikke ønsker at acceptere.

Den dag kommunaldirektøren eventuelt stopper, den dag bør kommunen også stoppe sin lønudbetaling. Hvis kommunaldirektoren så er utilfreds, kan han jo bare anlagge en retssag, siger gruppeformanden for den frie liste. 


\section{Dag 6 Flere hænder vaskes:}

Borgmesteren, 1. Viceborgmester og 2. Viceborgmester benægter medansvar. Alle benægter at have medansvar for den løbske økonomi i projektet, som kommunaldirektøren oprindeligt serverede for byrådet som gratis, men som nu har kostet kommunen flere mio. kr. Jeg føler ikke, at jeg har noget medansvar, men jeg føler til gengald, at kommunaldirektoren har rovrendt mig, siger 1. Viceborgmester.

\section{Intet nyt er altid godt nyt - ikke:}

Hvis det er meningen, at styregruppen skal holde oje med sin egen kommunaldirektor, er der noget galt. Det er ikke rollen for en styregruppe. Jeg er politiker, ikke revisor. Ingen af de tre borgmestre mener, at de af egen drift burde have søgt flere informationer end dem, de har modtaget fra kommunaldirektøren.

\section{Dag 8 - Først nu taler de tilfredse:}

Vurderingen af kommunens mest hotte kursus, som har sendt kommunaldirektøren ud i en orkan, medens politikerne bidrager med blæsebælg og trusler om fyring, er positiv. Ifølge de evalueringsskemaer, som kursisterne har udfyldt, er der overvejende tilfredshed. På en skala fra 15 lyder de foreløbige evalueringer på karakteren 4.13 fra medarbejderne og 3,99 fra lederne.

Inge deltog i kurset i november. Hun glædede sig til de 3 dage, og hun vendte ikke skuffet hjem. Jeg havde nu også hort meget godt om kurset forud. Kernevardier som kvalitet og ansvar er noget, man kan bruge $i$ sin hverdag. Nu er det igen lovligt at tilrettelagge arbejdet ud fra brugernes ønsker, medens der tidligere var mange regler for, hvad man måtte og ikke måtte. Hvis fx fru Jensen bad mig om at tage nogle rundstykker med, når jeg skulle mode naste morgen, så måtte jeg i princippet ikke handle for fru Jensen. Det var noget, jeg bare gjorde, selv om jeg vidste, jeg ikke måtte. I dag er det lovligt, og det har jeg det rigtigt godt med. Jeg synes det var en styrke, at vi blev blandet. At vi fik relationer til folk inden for andre fagområder.

Det var ikke blot et kursus, der skulle have mig eller min arbejdsplads til at fungere. Man tenker mere, at det var hele kommunen, det handlede om, og at det ikke blot var lederens ansvar, om arbejdspladsen fungerer. Jeg beklager, at et godt kursus er endt $i$ økonomisk slagsmål, kurset har ikke varet spildt, snarere tvartimod. 
Dag 10 - Der er stadig magtkamp:

Kommunens økonomiudvalg har i går behandlet økonomien i projektet. Det er vigtigt for $\varnothing$ konomiudvalget at understrege, at der er tale om et godt og perspektivrigt projekt.

Økonomiudvalget finder, at projektet er en fastslået del af medarbejderudviklingen i kommunen. 8 medlemmer af økonomiudvalget anbefalede, at projektet tilføres 2,5 mio. kr., og at der sættes aktiviteter i gang, der mindsker behovet for ny finansiering.

Et medlem af økonomiudvalget, formanden for den frie liste, deler ikke denne vurdering af projektet samt flertallets indstillinger. Han stillede i mødet forslag om, at der indledes en afskedigelsessag mod kommunaldirektøren. De øvrige medlemmer stemte imod.

\section{Dag 11: Modstanderne må have tilhængere på banen:}

Tre dages kursus ændrer ingen ting. Sådan er stemningen blandt en del af de ansatte i skatteadministrationen. Sagen er, at skattevæsnet arbejder efter måltal, mål som skal nås. Netop i år regner kommunen med, at skatteligningen kan indbringe fem mio. kr. mere end først beregnet, men politikerne har ikke givet anvisninger på, hvordan det skal gøres. Derfor var skattefolkene kede af, at de skulle på kursus, fordi de simpelthen ikke havde tid.

Jeg kan ikke andre på mine vardier, fordi jeg har varet på kursus med folk fra plejehjem og vuggestuer, siger en skattemedarbejder.

\section{$\underline{\text { Dag } 11 \text { Aben er endnu ikke placeret: Medlem hos de borgerlige }}$}

Jeg er rasende over det, der finder sted. Det er at satte manden i offentlig gabestok, allerede for byrådet har taget stilling.

Projektet er løbet økonomisk løbsk, og det anses for at vare Kommunaldirektorens ansvar; men jeg mener, at der også er et politisk ansvar. Der har varet en politisk styregruppe for projektet. Hvorfor skal vi have en styregruppe, hvis den ikke har noget ansvar? Kommunaldirektoren var praktisk talt hangt ved daggry gennem pressen. Projektet er kanon, og det er kommunaldirektoren også.

Man troede at $75 \%$ af medarbejderne kunne få tilskud, men det var kun $60 \%$ der kunne. Spørgsmålet var, om kommunens personaleorganisationer var tunet til at levere alle relevante oplysninger om personalesammensatningen. 


\section{E. Refleksion over projektforløbet}

Efterspillet resulterede i, at Byfornyerne fik deres politik igennem. Projektet blev afsluttet, og man vendte tilbage til den gamle kontrolkultur.

Projektet fik ikke den ønskede gennemslagskraft, kommunens gamle selvfortælling blev bekræftet, man vendte tilbage til kontrolkulturen og regelstyringen. Der var flere årsager til dette. Magtsystemet opfattede transformationsforløbet som lineært. Men et transformationsprojekt går gennem forskellige faser i et iterativt forløb. I udgangspunktet følgende fire faser:

\begin{tabular}{ll}
\hline Fælles formål & $\begin{array}{l}\text { En transformation må have et stærkt } \\
\text { fælles formål og en klar retning. }\end{array}$ \\
\hline Engagement & $\begin{array}{l}\text { Her mobiliseres kommitment i } \\
\text { organisationen. Involvering og autoritativ } \\
\text { kommunikation er helt centralt her }\end{array}$ \\
Transformation & $\begin{array}{l}\text { Her skabes og bruges nye kompetencer til at } \\
\text { udbygge personalets tillid og ændre deres } \\
\text { adfærd, holdninger og delte værdier }\end{array}$ \\
& $\begin{array}{l}\text { Her skal man forankre den nye ”business as } \\
\text { usual” og sikre at fremskridt bliver } \\
\text { konsolideret, at effekterne måles og at } \\
\text { efternølende adfærd adresseres. }\end{array}$ \\
\hline
\end{tabular}

Set $i$ bakspejlet kan man diskutere om projektet nogensinde kom forbi fase 1.

Løbende iterationer og parathed til at vende tilbage til de foregående faser i transformationscyklen for at løse problemer er et nøgleelement i enhver transformationsproces. Værdier skal holdes i live dagligt. Kommunen var nok for tidlige ude. Projektet mistede energien. Projektet har for mig illustreret, hvor nemt det er at ødelægge et plussumsspil, når flere af deltagerne i spillet spiller nulsumsspil, og når man ikke kan fastholde det fodslag, man blev enige om på byrådsseminaret.

Projektet har også illustreret, hvor svært det er for politikere at opgive enkeltsagsstyring, når de derved frasiger sig deres måske vigtigste magtmiddel, og gør sig selv sårbare. 
Det er forståeligt, at politik kan være nulsumsspil, når der er reelle konflikter, fx hvis det drejer sig om fordelingspolitik, værdikonflikter etc. Den eneste konflikt, jeg har kunnet få øje på i dette forløb, er konflikten mellem troen på stram regelstyring og kontrol kontra troen på tillid, motivation og fornyelse. Konflikten mellem at opfatte sine medarbejdere som x personer eller y personer, som Mc Gregor ville have udtrykt det.

Man kan undre sig over, hvorfor byrådet faldt tilbage til den adfærd, de selv betragtede som meget uhensigtsmæssig på byrådsseminaret. Man ville nemt have kunnet holde fast i beslutningerne fra seminaret, hvis man havde fulgt reglerne i den evolutionære stabile strategi, således som den er formuleret i Axelrod (1984). Det havde blot krævet en udgangssituation, hvor en ny fælles fremtid ville betyde meget, og hvor man havde tillid til hinanden.

I bogen ”En ny fremtid formes” af Russell L. Ackoff står der på første side:

"Hvis du laser avisen og stadig er tilfreds med forholdene $i$ verden og synes, at alt er godt, så lag denne bog til side, den er ikke til dig. Mit formål er ikke at omvende dem, der er tilfredse, skont jeg mener, de har omvendelse behov; men at give dem, der er utilfredse, grund til håb og noget at gøre ved det."

Og videre skriver han:

"En persons evne til at lede sine eller sit samfunds forhold afhanger mere af hans forståelse af og hans holdning til den verden, han er en del af, end af hans problemlosningsmetoder. Sagt på en anden måde, afhenger hans succes mere af hans syn på verden, og af den filosofi han lever efter, end den afhanger af videnskab og teknologi. For at problemlosning kan få succes, skal man finde den rigtige løsning til det rigtige problem. Vi laver oftere fejl, fordi vi loser det forkerte problem, end fordi vi løser det rigtige problem forkert." 


\section{Sporgsmål}

Som nævnt i indledningen vil vi gerne have Jeres refleksioner over det forløb, som er beskrevet i casen. Hvad er det, vi skal gøre bedre for at undgå situationer, der ligner den i casen. Vi ser 3 parter her, som fremover bør kunne spille bedre sammen. Nemlig:

1. Bestiller - Her kommunen

2. Udfører - Her konsulentfirmaet

3. Uddannelsesinstitutionerne - Dem som skal sikre de nødvendige kompetencer til såvel bestiller som udfører.

Tegnes projektets storyline kan den illustreres således:

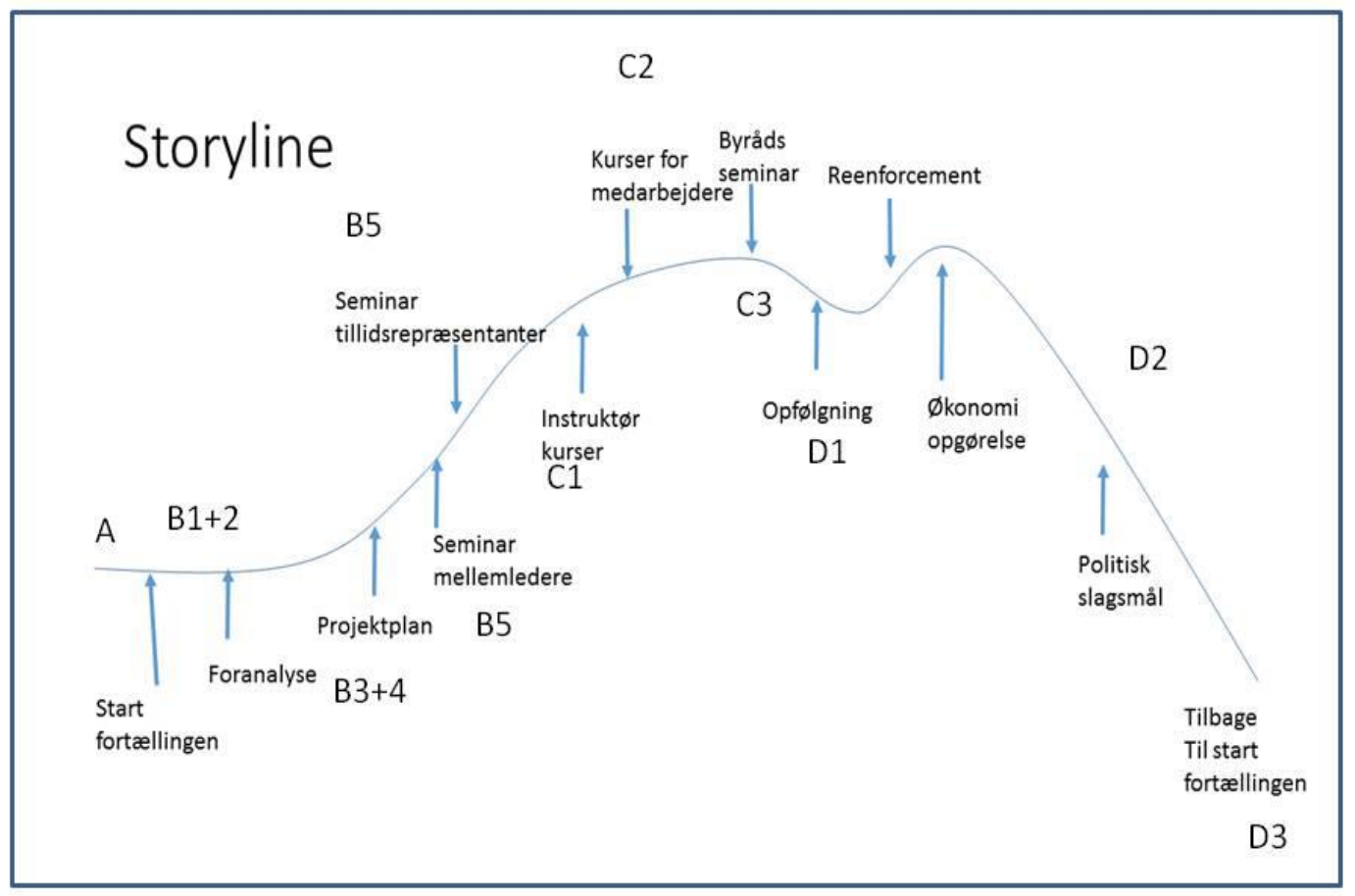

\begin{tabular}{|l|l|}
\hline Afsnit & Spørgsmål \\
\hline A. Projektet. & $\begin{array}{l}\text { Hvordan kan konsulent- og rådgivningsfirmaer sikre sig, at } \\
\text { opdragsgiveren ved, hvad det er, han bestiller? } \\
\text { Og hvordan kan de sikre sig, at bestillerorganisationen er rustet til at } \\
\text { modtage det, de har bestilt? }\end{array}$ \\
\hline
\end{tabular}




\begin{tabular}{|c|c|}
\hline & $\begin{array}{l}\text { Vil opdragsgiver ikke blot finde et andet firma, hvis konsulentfirmaet } \\
\text { lægger afgørende vægt på at få opdragsgiverne til at kommitte sig til } \\
\text { at spille en langt større rolle som transformationsledere, end den, } \\
\text { som de først havde forestillet sig? }\end{array}$ \\
\hline $\begin{array}{l}\text { B.1 Opstartsmøde med } \\
\text { direktionen. }\end{array}$ & $\begin{array}{l}\text { Hvorfor ser direktionen ikke sin egen adfærd som noget, man skal } \\
\text { ændre og følge op på? } \\
\text { Er det realistisk at satse på frisættelse, tillid og ejerskab i en kultur, } \\
\text { der er gennemsyret af markant regelstyring, kontrol og korrektheds } \\
\text { bulimi? } \\
\text { Kan man forvente at mellemlederniveauet træder frem i en sådan } \\
\text { transformationsproces? } \\
\text { Hvad kan man gøre som modspil for at løse disse paradokser? }\end{array}$ \\
\hline B.2 Diagnosen. & $\begin{array}{l}\text { Er det rigtigt, at lederskab forudsætter, at man kan høre, hvad } \\
\text { organisationen siger om sig selv? } \\
\text { Hvordan sikrer lederne at kommunikationen nedefra ikke filtreres } \\
\text { uhensigtsmæssigt, og bør de tage den alvorligt, hvis man ikke er enig } \\
\text { i eller ikke kan lide det, man evt. hører? } \\
\text { Hvad kan medarbejderne blive stolte af i en splittet og demotiveret } \\
\text { organisation? }\end{array}$ \\
\hline $\begin{array}{l}\text { B.3 Opstilling af } \\
\text { projektets succeskriterier. }\end{array}$ & $\begin{array}{l}\text { Giver det nogen mening at opstille succeskriterier, når man ikke har } \\
\text { en realistisk plan, der viser, hvordan man opnår dem? } \\
\text { Kan en realistisk plan være den, at dem, vi delegerer opgaven til, vil } \\
\text { sikre, at vi når de succeskriterier, vi har opstillet? } \\
\text { Hvorfor reagerer magtsystemet ikke på det, ændringen forudsætter } \\
\text { af magtsystemet, således som det, den kommunale selfie viste? } \\
\text { Er det muligt at reformere adfærden i magtsystemet i et anarki? }\end{array}$ \\
\hline $\begin{array}{l}\text { B.4 Formulering af vision } \\
\text { og fælles værdigrundlag. }\end{array}$ & $\begin{array}{l}\text { Er vi opmærksomme på betydningen af en fælles vision? } \\
\text { Kan vi se, om den er delt eller blot en "skuevision”, som medarbejdere } \\
\text { og medledere ikke tager ejerskab af? } \\
\text { Hvad ville det have krævet, at gøre visionen i casen til en fælles og } \\
\text { delt vision? }\end{array}$ \\
\hline $\begin{array}{l}\text { B.5 Afholdelse af } \\
\text { mobiliseringsmøder. }\end{array}$ & $\begin{array}{l}\text { Hvorfor agerede magtsystemet ikke mere markant på det } \\
\text { organisatoriske selvbillede, som gentagne gange blev tegnet under } \\
\text { projektforløbet? }\end{array}$ \\
\hline
\end{tabular}




\begin{tabular}{|c|c|}
\hline & $\begin{array}{l}\text { Hvordan burde magtsystemet have brugt mobiliseringsmøderne til } \\
\text { at skabe det nødvendige ejerskab, som kunne have sikret } \\
\text { forankringen af den ændring, man havde bestilt og igangsat? }\end{array}$ \\
\hline $\begin{array}{l}\text { C.1 } \\
\text { Instruktøruddannelsen. }\end{array}$ & $\begin{array}{l}\text { I hvilken udstrækning kan man lykkes med en } \\
\text { organisationsudvikling blot med et train the trainer forløb, når } \\
\text { trainerner ikke har praktisk organisationsudviklings erfaring, og når } \\
\text { de ikke må intervenere i feltet efter kurserne? }\end{array}$ \\
\hline $\begin{array}{l}\text { C2. } \\
\text { Medarbejderuddannelsen. }\end{array}$ & $\begin{array}{l}\text { Er vi opmærksomme nok på, hvornår et kursus blot vil blive } \\
\text { indkapslet træning? } \\
\text { Hvad der efterfølgende skal til for at kurserne internaliseres? }\end{array}$ \\
\hline C.3 Byrådsseminaret. & $\begin{array}{l}\text { Listen over spilleregler lyder som et udpluk at } \\
\text { ledelseskommissionens anbefalinger. Hvad skal der til, for at det ikke } \\
\text { kun bliver en ønskeliste uden bund i virkeligheden? } \\
\text { Hvordan kunne byrådet i længere tid leve med en arbejdssituation } \\
\text { som den her beskrevne? } \\
\text { Er Kanters pointer om manglende tiltro et godt svar? } \\
\text { Og hvis ja hvordan slipper man så ud af beslutningskulturen, når } \\
\text { byrådet er toppen af magtsystemet? } \\
\text { Hvad gør man, hvis byrådet, som den øverste del af magtsystemet, er } \\
\text { et taberhold? }\end{array}$ \\
\hline D.1 Virkningsevaluering. & $\begin{array}{l}\text { Bekræfter virkningsevalueringen Torben Beck Jørgensens } \\
\text { konklusioner om initiativer i værdibrede kommuner, hvis ja hvordan } \\
\text { skal vi så forholde os til det? } \\
\text { Hvordan kan vi få forskellige fagligheder til at respektere hinanden } \\
\text { og samarbejde bedre? }\end{array}$ \\
\hline D.2 Efterspillet. & $\begin{array}{l}\text { Hvorfor lader byrådet sig føre tilbage til den adfærd, man som } \\
\text { byrådsmedlem ikke kan lide, oven i købet når man ved, det skader } \\
\text { kommunen? } \\
\text { Er en god skandale det vigtigste, hvis man vil øge egne politiske } \\
\text { magtmidler? } \\
\text { Kan pressen være bekendt at gengive alt, hvad den får serveret? }\end{array}$ \\
\hline
\end{tabular}




\begin{tabular}{|l|l|}
$\begin{array}{l}\text { D.3 Undren over } \\
\text { projektforløbet. }\end{array}$ & $\begin{array}{l}\text { Hvad skal der til i en politisk forsamling, hvor kulturen i lang tid har } \\
\text { været fnidder, nulsumsspil, skjulte dagsordner etc., for at man kan } \\
\text { skabe en fælles fremtid og etablere et tillidsforhold til hinanden? } \\
\text { Er det nok alene at formulere fælles spilleregler, som dem, der blev } \\
\text { lagt op til på byrådsseminaret? } \\
\text { Har Ackoff ret i det han skriver? Og lægger universiteter og } \\
\text { læreanstalter for meget vægt på videnskab og teknologi og for lidt } \\
\text { vægt på værdier og holdninger? } \\
\text { Når vores projekter går galt, er det så ofte på grund af holdninger og } \\
\text { de begrænsninger, det giver i vores erkendelser? } \\
\text { Og hvis ja, hvordan kunne vi have håndteret det? }\end{array}$ \\
\hline
\end{tabular}

\section{Litteratur}

Ackoff Russell (1976) "En ny fremtid formes: systemteorien anvendt på samfundsproblemer";

Erhvervsøkonomisk Forlag.

Axelrod Robert (1984) "The Evolution of Cooperation”; Basic Books.

Empowering change fostering innovation in the Australian public service - management advisory service - Commonwealth copyright administration 2010, isbn 978-0-642-72633-9.

https://www.apsc.gov.au/sites/g/files/net5296/f/empoweringchange.pdf

Frey S. Bruno \& Reto Jegen (2000): "Motivation Crowding Theory. A Survey of Empirical Evidence, revised version". Working Paper Series, Institute for Empirical Research in Economics, University of Zurich, juni. http://pages.towson.edu/jpomy/behavioralecon/freygeeare97.pdf

Jørgensen, Torben Beck (red) (2003): "På sporet af offentlig identitet, Vardier I stat, amter og kommuner"; Århus Universitetsforlag.

Mc Gregor, D. (1960): "The Human Side of Enterprise”;Mc Graw Hill; New York.

Moss Kanter, Rosabeth: (2006); "Confidence: How Winning Streaks and Losing Streaks Begin and End”; Three Rivers Press; New York.

Oosterwaal, Annemarije \& Rene' Torenvlied (2011): "Policy Divergence in Implementation: How Conflict among Decisive Legislators Reinforces the Effect of Agency Preferences”; Journal of Public Administration Research and Theory; 12 july.

Ringgaard, Hermod et al (2008): "Forandringens irrationelle ekko; 2008; Syddansk universitet. 
Beyer / Kampen om den organisatoriske selvfortælling

Senge, Peter (1990); "The Fifth Disciplin: The Art and Practice of the Learning Organization, New York; Doubleday.

\footnotetext{
${ }^{1}$ Se https://www.denoffentlige.dk/her-er-ledelseskommissionens-syv-anbefalinger

${ }^{2}$ Dette kan demonstreres med et eksempel: Når en hjemmehjælpen snakker med en borger, spørger hjemmehjælpen: "Hvordan går det, er der noget nyt? Hjemmehjælpen opfatter borgeren som en hel person, som et subjekt. Den kommunale visitator skal bruge sin faglige, juridiske ekspertise. Han/hun kunne på baggrund af de forskellige udtalelser, som kommunen har indhentet, sige, du er bevilget x timers hjemmehjælp. Og ved sådanne visitationer er borgeren mere et objekt for visitator, der betragter borgeren som en genstand, der skal klassificeres (som en geolog kigger på en sten).
} 